\title{
NÓS, OS ARQUITETOS DOS SEM-TETO WE, THE ARCHITECTS OF THE HOMELESS
}

\author{
JoÁo Marcos de Almeida Lopes \\ Universidade de São Paulo, Instituto de Arquitetura e Urbanismo, São Paulo, SP, Brasil
}

\begin{abstract}
R E S U M O : A partir do relato de duas situaçôes de trabalho envolvendo a interlocução entre arquitetos e movimentos sociais, este artigo procura demonstrar como a prática do ofício em contextos inusitados escapa dos protocolos formais, denegando caracterizaçôes generalistas - como "o arquiteto", "a arquitetura", "o mercado" etc. - bem como possíveis enquadramentos semânticos mais apertados. Procura-se demonstrar o quão frágeis se tornam as designações mais flexíveis ou as conceituaçôes mais rigorosas, frente a uma realidade instável e que não admite os protocolos tradicionais da prática do ofício. A partir dos relatos e dessas conjeturas, sugere-se que a profissão, atualmente esvaziada de seu sentido público e esgarçada nos limites de seus compromissos mais mundanos, deve ser reinventada. Especula-se então quanto às possibilidades de o ofício assumir novos conteúdos e modificar estruturalmente o modo como opera suas atribuiçóes práticas.
\end{abstract}

P A L A V R A S - C H A V E : Atuação profissional; produção do habitat; moradia e autogestão.

A B S T R A C T : From a report of two work situations involving a dialogue between architects and social movements, this article attempts to demonstrate how professional practice in unusual contexts escapes the formal protocols, thereby denying generalized characterizations - such as 'the architect', 'architecture' or 'the market' etc. - as well as possible tighter semantic frameworks. The article also attempts to reveal how fragile the more flexible designations become or conceptualizations more rigorous, when facing an unstable reality, thereby denying the traditional protocols of professional practice. From the descriptions and these conjectures, it is suggested that the profession, currently deflated of its public sense and squeezed within the limits of its most mundane commitments, must be reinvented. We therefore speculate as to the possibilities of the profession in assuming new contents and structurally modifying the manner in which it operates its practical attributions.

KEYWORDS: Professional practice; habitat production; housing and self-management

DOI: https://doi.org/10.22296/2317-1529.2018v20n2p237 
1 Ver http://www.caubr. gov.br/56a-plenaria-caudestinara-recursos-para-projetos-e-obrasde-assistencia-tecnica/ - agradeço à mestranda Fernanda Simon, do Instituto de Arquitetura e Urbanismo da USP, pelo acesso à notícia.
Nós, arquitetos que trabalhamos há algum tempo diretamente com os movimentos sociais - particularmente, os movimentos de sem-teto e sem-terra e com maior frequência no contexto do estado de Sáo Paulo - fomos recentemente surpreendidos pela ocorrência de um seminário sobre Assistência Técnica em Habitação de Interesse Social (ATHIS) na capital paulistana.

Promovido pelo Conselho de Arquitetura e Urbanismo do estado de São Paulo (CAU/SP) entre os dias 23 e 24 de novembro de 2017, esse seminário pretendia claramente dar alguma resposta (ainda que absolutamente insuficiente, já adianto) à determinação do CAU nacional para que cada CAU da Federação implementasse, já em 2017, a aplicação de $2 \%$ de sua receita líquida em programas e projetos de Assistência Técnica em HIS.

O Conselho que rege a categoria dos arquitetos e urbanistas no Brasil vem buscando, desde sua criação em 2010 (antes, compartilhávamos, com engenheiros e agrônomos, um mesmo conselho profissional - os Conselhos Regionais de Engenharia, Arquitetura e Agronomia (CREAs), consolidar os limites do campo de atuação destes profissionais, buscando definir de modo um pouco mais preciso os contornos de suas atribuiçóes. No contexto desse esforço, surgiram discussóes sobre a dimensão pública do trabalho do arquiteto e quanto às possíveis açóes para que esse trabalho passasse a ser acessível a um contingente maior da população. Embalados por esta orientação, os conselheiros federais decidiram então - conforme encaminhado na 56 Plenária Ordinária do CAU/BR, realizada entre os dias 21 e 22 de julho de 2016 - que todos os CAUs da Federação deveriam prever, em suas diretrizes orçamentárias a partir de 2017, a aplicaçáo de, no mínimo, 2\% das receitas de arrecadação (referentes às anuidades pagas pelos profissionais e aos recolhimentos de Registros de Responsabilidade Técnica - além de taxas e multas aplicadas pela fiscalização) em programas e açôes de Assistência Técnica em Habitação de Interesse Social - o que vem se consolidando como ATHIS ${ }^{1}$. No caso paulista, não é valor desprezível: em 2017, tratava-se de $\mathrm{R} \$ 706.370,23$, previstos como Despesa Corrente sob a rubrica 02.03.003 "Assistência Técnica em Habitaçôes de Interesse Social” (CAU/SP, 2017a). É claro que, a depender da orientaçáo dada para aplicaçáo do recurso, sua efetividade pode ser bastante reduzida - em termos de incentivo para a área habitacional, nem é assim tanto dinheiro. Entretanto, considerando o papel que um conselho profissional como o CAU poderia cumprir, esses são recursos valiosíssimos que poderiam contribuir para a implementação de políticas de fomento e articulação de açôes de ATHIS.

No entanto, pelo menos no caso paulista, não foi o que aconteceu, como se verá a seguir. Mas foi o que se pretendeu, com o tal seminário sobre ATHIS, no final de 2017: anunciando reunir "autoridades e especialistas", o CAU/SP proclamava como objetivo do seminário, no sítio de divulgação do evento, "discutir a aplicação dos recursos destinados à Assistência Técnica em Habitaçâo de Interesse Social (ATHIS)”, apresentando "palestras e debates sobre as origens da Assistência Técnica; a implementação da Lei n. ${ }^{\circ} 11.888$; as experiências de assistência técnica no Brasil; e pesquisas relacionadas ao tema" (CAU/SP, 2017b).

Um pretensioso escopo para pouco efeito prático: afundada na autorreconhecida inoperância burocrática da autarquia, atolada numa inconciliável disputa política interna e à vista do iminente término de seu mandato, a direção do Conselho atropelou abruptamente a própria instância que seu plenário designara, já no início desta última gestão, como aquela responsável por lidar com essa temática: um dentre os diversos 
Grupos de Trabalho temáticos vinculados à diretoria do Conselho regional, o GT sobre ATHIS. Incumbido de, num primeiro momento, discutir o papel do CAU no campo da Assistência Técnica em HIS e, posteriormente, já em março de 2017, as possíveis formas de aplicação da cota de $2 \%$, conforme deliberado pelo CAU nacional, esse GT vinha realizando reuniôes regulares e havia, inclusive, sugerido a realização de um seminário sobre o assunto. No entanto, à sua revelia, a direção do CAU/SP montou o seu próprio seminário, muito mais preocupada em dar uma resposta esperta e apressada a qualquer possível insinuaçáo de improbidade administrativa - uma vez que a determinaçáo do CAU/BR não havia sido cumprida pelo CAU/SP.

Para não sermos injustos, o evento até conseguiu trazer figuras que alcançaram alguma projeção no debate sobre o assunto - como é o caso do deputado gaúcho Clóvis Ilgenfritz, principal articulador, junto com o já falecido deputado baiano Zezéu Ribeiro, das ações parlamentares que culminaram na aprovação da Lei n. ${ }^{\circ} 11.888$, em 24 de dezembro de $2008^{2}$. No entanto, de saldo, o evento acabou contribuindo muito pouco para aprofundar o debate, delimitar mais claramente o que seria o campo de atuação dos profissionais dedicados à Assistência Técnica, traçar possíveis estratégias para a implementação de políticas públicas na área etc.; tanto menos, para delinear possibilidades práticas de aplicação da cota de $2 \%$.

Por outro lado, o evento foi muito oportuno para nos fazer ver mais claramente os sinais dos deslizamentos semânticos que já se insinuavam por entre os arranjos práticos que eventualmente se apresentavam como "assistência técnica", "assessoria técnica", "arquitetura pública" ou "de interesse social", como "arquitetos da família" ou "da comunidade" etc. As práticas, realizadas em contextos bastante diversos e difusos, acabam procurando uma espécie de autojustificação terminológica, tomando alguma denominaçáo bem ajeitada como enunciado que se possa chamar de seu.

É claro que nem todas as experiências ali apresentadas correspondiam à caracterização anterior. Várias delas dispunham de lastro próprio e contornos mais bem definidos: como já dito, a coordenação do evento fez um juntado sem muito critério e sem muito conhecimento das especificidades dessa área de atuação. Assim, desde a apresentação do muito bem-vindo programa de residência profissional promovido pela Faculdade de Arquitetura da Universidade Federal da Bahia, até proposiçóes mais voluntaristas de profissionais engajados em oferecer seus serviços nas periferias das grandes cidades, passando por um inusitado "plano de negócios" em reformas baratas (uma startup contando como faz dinheiro vendendo pequenas reformas em bairros precários ${ }^{3}$ ), formou-se ali um quadro muito difuso e bastante atravessado por ambiguidades que, principalmente em virtude da forma como foi conduzido o parco debate, mais contribuiu para aprofundar as dúvidas e confusóes do que para o aclaramento da temática.

Sem dúvida, uma rigorosa exegese dos termos não deixa de ser imprescindível para a formulação de alguma crítica mais produtiva, buscando um delineamento mais acurado de um campo de trabalho que náo pode ser abordado sem alguns cuidados: do que se trata, efetivamente, a Assistência Técnica à Habitação de Interesse Social? Em suas versôes mais rasteiras, a apropriação dessa terminologia - em alguns casos parece servir apenas para justificar o pronto atendimento de arranjos negociais de ocasião, como já disse, sempre a postos e dispostos a prestar seus serviços, sempre atentos a qualquer oportunidade oferecida pelo "mercado".

Neste sentido, parece-me eloquente a fala do arquiteto Haroldo Pinheiro, então
2 De acordo com algumas fontes, o arquiteto e deputado Clóvis Ingelfritz sempre foi um entusiasmado defensor da assistência técnica "pública e gratuita" - entusiasmo claramente reafirmado no evento de novembro de 2017. Para mais informações a respeito, ver IAB (2010); Santo Amore (2017); e Demartini (2016).

3 Disponível em: http:// p rogramavivenda. com.br. Acesso em: mar. 2018. Na mesma linha, há também iniciativas como o Inova Urbis. Disponível em: http://www. espacodopovo.com.br/ escritorio-popular-de-arquitetura-chega-em-paraisopolis-e-oferece-projeto-de-reforma-degraca/. Acesso em: mar. 2018. 
presidente do CAU/BR, na ocasião do encaminhamento da destinação dos $2 \%$ dos CAUs para programas de ATHIS: "A decisão do Plenário objetiva alavancar o espaço de trabalho do arquiteto junto à população mais carente na realização de projetos e obras" (CAU/BR, 2016).

No entanto, iniciativas como esta ou como o seminário de novembro de 2017 em São Paulo não deveriam ter como objetivo "alavancar" as oportunidades de trabalho dos arquitetos - por mais nobre e honesta que seja a intenção - mas, sobretudo, deveria estimular e promover o sério debate quanto às saídas para um problema público de abrangência nacional e que aflige não só a população imediatamente implicada como também todos os grandes e médios centros urbanos do país, em todas as suas dimensôes sociais e funcionais. Como diz Caio Santo Amore, "a ampliação do mercado de trabalho para os arquitetos e urbanistas é, afinal, consequência de uma política habitacional inclusiva e abrangente, não o seu contrário. Ou seja, a política habitacional náo pode ter como fim a política de uma categoria profissional" (SANTO AMORE, 2017, p. 10).

Talvez em virtude de tais deslizamentos - semânticos e até mesmo práticos - é que remanescem questóes quanto aos sentidos do que venha a ser o "mercado de trabalho" dos arquitetos por excelência. Trata-se de um serviço destinado a uma elite econômica e náo se discute mais isso? Haveria um "mercado de trabalho popular" e outro "tradicional"? Que tipo de ser humano constitui essa "categoria profissional"? Seria possível imaginarmos um "arquiteto-militante" em oposição a um "arquiteto de mercado"? Ou, por outro lado, seria adequado imaginarmos um "arquiteto-tipo" forma, modelo e padrão - gabarito ou referência para o reconhecimento de quem seria "mais" ou "menos" arquiteto?

João Whitaker propôs-se, em artigo publicado na Arquitextos do Vitruvius em 2011, a abordar esse assunto. Diz o autor, a determinada altura do texto: "A extrema centralização em torno de um único modelo profissional é apenas o reflexo de um processo social pelo qual a profissão da arquitetura colocou-se em uma posição de elitização e de afastamento da realidade urbana...”. Até esse ponto, fecho acordo com o autor, principalmente se considerarmos a circulação midiática e a intensa louvação do arquiteto "de encomendas".

No entanto, a ideia segue e acho que a formulação não chega no ponto onde acredito residir o nó da questão. Parece-me, no texto, que o problema é a conexão "causa -efeito" ali defendida. Conforme Whitaker, o efeito a que se refere é “...decorrência do longo período de autoritarismo e de políticas econômicas de extrema concentração da renda" (WHITAKER, 2011, p. 4). Creio que o problema é maior. O problema é histórico e estrutural - e não conjuntural. $\mathrm{E}$, se isso é verdade, não se trataria aqui de nos afundarmos numa "polêmica semântica", como diz Caio Santo Amore (2017, p. 5).

Para os devidos efeitos, caberia cogitarmos se não é o caso de, talvez, refundarmos o ofício, a própria profissão.

Para ilustrar a posterior verificação da hipótese aqui formulada, relato a seguir duas situaçôes de trabalho, envolvendo arquitetos e sem-terra ou sem-teto ou semdireitos, nas quais as abordagens técnicas mais corriqueiras viram-se afrontadas por injunçóes e demandas que nos fizeram pensar a posiçáo relativa que o profissional 
denominado "arquiteto" ocupa quando se confronta, sem os aparatos institucionais e os salamaleques da profissão, com as antinomias e contradiçóes de uma realidade que nunca foi plenamente experimentada por aqueles que ocupam as pranchetas das nossas escolas de arquitetura.

Falo aqui como integrante da USINA - Centro de Trabalhos para o Ambiente Habitado ${ }^{4}$. Fui um dos seus fundadores e ainda hoje articulo algumas de minhas pesquisas ao cotidiano de trabalho ali desenvolvido - logo, assumo um lugar de fala e é dali que enuncio os breves relatos dos quais farei uso mais adiante.

\section{AS ARTIMANHAS DO DISCURSO BIFRONTE}

\section{I}

Pelos idos dos anos 1980, nas diversas circunstâncias em que nos vimos às voltas com o ideário dos movimentos sociais - e aqui, relembro, trato dos movimentos de moradia -, pareciam-nos naturais e muito promissores, se não incorro no engano da generalização, a permeabilidade e o emparelhamento das expectativas que as partes então mutuamente engajadas faziam manifestar. Naquele momento, eram essas expectativas que orientavam as práticas, àquela hora muito engajadas na construçáo de um amplo processo de transformação social, que esperávamos como que a reboque da proliferação dos projetos de produção de moradia por ajuda mútua e por autogestáo que se afirmaram ao longo daquele período na cidade de São Paulo.

Boa parte das formulaçóes que embaralhavam o trabalho técnico e a militância política, dos projetos urbanísticos e arquitetônicos que se estendiam para além de seus limites estritamente construtivos, dos debates e práticas conduzidos e construídos entre muitas dificuldades ao longo dos anos 1980 e começo dos 1990, alimentava um imaginário que nos fazia crer nas possibilidades e potencialidades transformadoras das práticas autonomistas atreladas àqueles processos de produção da moradia. Como a polia na correia de transmissão, tais práticas fariam construir a "consciência da autonomia", estendendo os pressupostos de uma "gestáo autônoma da vida" para outros âmbitos da produção e reprodução da existência.

Se não exagero, era discurso corrente pretendermos ensaiar modos mais evoluídos de relaçôes de produção, de gestão e cuidado com a vida e de participação direta nas decisóes que implicavam o cotidiano coletivo. Em suma, um discurso de autodeterminação e autonomia. Assim como aparecia em seus contornos, esse discurso permitia imaginar que, após construída a moradia, abrigados os corpos e instalados os desejos particulares sob o teto produzido coletivamente e a partir do esforço próprio, aqueles construtores haveriam de alcançar também a construção de uma "consciência de autonomia", uma espécie de "desejo autodeterminado de autodeterminação", negando a submissão a um poder que lhes é externo, que não emana de si mesmos, e tomariam para si a construção livre e autônoma de sua própria existência.

Insisto que, apesar da conjugação do parágrafo anterior insinuar algo entre ingenuidade e ironia - à vista dos tempos atuais -, nada havia de "romântico" nas confabulaçôes e formulaçôes daquele período: as tensóes cotidianas e as impiedosas engrenagens da prática náo deixavam espaço para algum envolvimento, digamos, propriamente "apaixonado". Não era nada agradável consumir nosso tempo livre na
4 A USINA é uma associação civil sem fins lucrativos. Fundada em 1990 e reconhecida como um grupo de "assessoria técnica", a USINA vem atuando intensamente, ao longo dos 27 anos de sua existência, contribuindo técnica e politicamente para a viabilização de mais de 6 mil moradias por ajuda-mútua e autogestão, elaborando projetos e conduzindo as obras para sua produção.

5 Recupero aqui, em parte, um artigo apresentado no XII Encontro da Associação Nacional de Pós-Graduação e Pesquisa em Planejamento Urbano e Regional, ocorrido entre os dias 21 a 25 de maio de 2007, em Belém do Pará. 0 título completo é "As artimanhas do discurso bifronte: práticas de autonomia e ambiguidade discursiva na gestão de projetos sociais nos mutirões em São Paulo". 
poeira dos canteiros de obras, muitas vezes dispostos a tensóes críticas e pouco amistosas. Por outro lado, não seria legítimo identificar, sem mediações, aquela composição discursiva como "construção ideológica" em termos absolutos: a percepção crítica daquela realidade, em certa medida, nunca deixou de ser uma parceira cotidiana. Para quem olha de lado ou de fora, se parece próprio do distanciamento crítico escapar do regime transparente que nos produz ideologia - o que não é verdade -, por outro lado lhe é próprio conduzir à conclusão velada de que o prático não necessariamente indaga sobre sua própria prática. É esse distanciamento também que, tantas vezes, leva o crítico a abraçar o lado aparentemente "fraco" da relação, não se perguntando sobre a "origem das ideologias" e, "na ausência de tais indagaçôes, os dominados, no final das contas, deixam de ser o negativo para reduzirem-se à condição dos eternos logrados pelo poder diabólico dos dominantes" (CHAUÍ; FRANCO, 1978, p. 15). Considerá-los assim facilita enormemente a funcionalidade analítica tradicional, condenando como "primarismo romântico" as formulaçōes gestadas pelas engrenagens do mundo da vida.

De qualquer forma, em diversas ocasióes e juntamente com vários grupos de construtores autônomos, trabalhamos a possibilidade da gestão livre dos serviços destinados ao atendimento das necessidades coletivas: da creche ao ensino superior, do posto de saúde ao hospital, do ponto de ônibus à rede pública de transporte, do sacoláo a esquemas de abastecimento estruturados a partir da associação com assentamentos rurais geridos pelos trabalhadores sem-terra. Compartilhávamos com as lideranças dos movimentos - e, em boa medida, também com boa parte do povo com que nos colocávamos a ombros - a expectativa de instituirmos, ao término das obras, grupos e conselhos de gestão que assumiriam, pelas próprias mãos, a formulaçáo, o planejamento, o caráter e o destino daqueles serviços, suprimindo, em boa tradição libertária, a dependência de um Estado que apenas obstrui a possibilidade de autodeterminaçáo dos trabalhadores a partir de suas organizaçóes livres e autônomas.

\section{II}

Se forço nas cores, não é porque me situo como o cético que vê com ironia suas convicçóes juvenis. Pelo contrário, em alguma medida, aquelas expectativas originais vêm se realizando.

E é justamente isso que intriga: se compartilhávamos, técnicos e construtores autônomos, os mesmos pressupostos de autonomia e autodeterminaçáo, por que hoje não reconhecemos, nas práticas cotidianas instaladas nos conjuntos que ajudamos a construir, sequer um contorno de afinidade com os discursos que afiávamos juntos?

Em diversos conjuntos de moradias produzidos por mutirão e autogestão - e aqui me refiro particularmente a São Paulo e sua região metropolitana - não é incomum a prática de inúmeros "projetos" nos quais se engajam lideranças comunitárias e grupos de moradores que cuidam, de forma escrupulosa e autenticamente autônoma, de empreendimentos sociais destinados ao cuidado e ao atendimento da coletividade mais circunvizinha. São "projetos" que envolvem atividades de abastecimento e comércio de gêneros (padarias, armazéns e sacolóes comunitários), formação profissional ou ocupação produtiva (cursos de panificação, de informática, artesanato ou costura), educaçáo e ocupação do tempo livre fora da escola (creches conveniadas, desenvolvimento de programas de reforço escolar e de atenção a jovens em "condições de risco"), 
assistência social (apoio a dependentes químicos, auxílio à maternidade, balcão de empregos etc.) e de cultura (música, identidade negra, teatro, audiovisual etc. etc.). São "projetos" normalmente subsidiados com recursos obtidos através de convênios com segmentos do poder público, com agências governamentais e não governamentais de financiamento, com organismos internacionais ou mesmo com o apoio de organizaçôes vinculadas à Igreja, nacional e, principalmente, internacional ${ }^{6}$.

Estes "projetos" criam uma sociabilidade peculiar e propóem uma espécie de "cultura autogestionária”, uma cultura essencialmente urbana e periférica, de práticas estabelecidas a partir da articulaçáo de uma "consciência de autonomia" paradoxalmente em simbiose com os intrincados mecanismos de controle e administração das açôes por eles propostas. Vinculam-se ao espaço da moradia - como imaginávamos -, articulam e agregam internamente a participaçáo ativa dos moradores, negam a intervenção do Estado, anunciando que dele apenas esperam que não atrase as parcelas dos financiamentos, e correspondem, até que em boa medida, àquela expectativa que cultivávamos ao longo dos anos 1980 e começo dos 1990.

No entanto, dando provimento à "confluência perversa" (DAGNINO, 2002), fica fácil compreendermos o quanto a prática compensatória de certa forma conduzida por esses "projetos" pode ser útil à perspectiva neoliberal de enxugamento dos deveres do Estado. Além disso, o padrão das ações propostas pelos "projetos" facilmente confunde-se com o engajamento assistencialista de terceiro setor, proliferando ainda mais a "cidadania empresarial" que ascendeu com muito vigor desde os 1990. Dessa forma, a autonomia que pregávamos não se parece com a autonomia que hoje os movimentos praticam. A autodeterminação produtiva, transformadora e libertária não se assemelha à autodeterminação profilática que os tais "projetos" parecem preconizar. E, no entanto, a cadeia genética das duas concepçôes parece conjugar os mesmos códigos originais.

Para nós, técnicos, as referências para uma cultura política associativa eram e são, em boa medida, eurocêntricas, principalmente se considerarmos a vertente discursiva ligada à tradição libertária e anarquista. Quando formulávamos nossa concepção de organizaçôes autônomas de gestão da vida na cidade, tínhamos como referência as corporaçóes livres preconizadas pelos utopistas do XIX, as comunidades produtivas socialistas, as comunas de moradores que geriam o local imediato da moradia etc. Cabiam também outras referências exógenas, como as cooperativas uruguaias de produção de moradias por ajuda-mútua e autogestão. A proximidade geográfica e algumas similaridades socioeconômicas, no entanto, não justificavam imaginarmos replicáveis os expedientes lá adotados, principalmente se levássemos em consideração a relativamente longa tradição cooperativista daquele país ${ }^{7}$.

Ou seja, quando falávamos, movimentos e técnicos, em "autonomia", "autodeterminação" e "autogestáo", colocávamos em jogo uma teia de sentidos e significados que se estruturavam a partir de genealogias distintas. Como uma forma bifronte, tínhamos, diante de nós, duas faces da mesma face e, mesmo que considerássemos discutir as propriedades e os fundamentos do discurso, pouco importava - ou não percebíamos a importância de - perguntar quanto à identidade genética de tais fundamentos. Daí significados distintos para até mesmo atributos discursivos idênticos: a autonomia nos modos de organização produtiva, a autodeterminação popular em relação ao Estado, o regime de autogestão para controle da vida coletiva etc. No entanto, a ordem dos fatores alteraria radicalmente o resultado.
6 Isso quando não se trata de pecúlio angariado junto aos próprios moradores ou participantes do "projeto": como reclama Caio Santo Amore, "isso não é plausível como política pública! Não é plausível que as famílias mais vulneráveis tenham que financiar os projetos de viabilização dos empreendimentos, com um nível muito alto de incertezas e riscos de não viabilização" (SANTO AMORE, 2016, p. 17).

7 Sobre essa incompatibilidade ver LOPES; RIZEK, 2006. Sobre a experiência uruguaia de produção de moradia por ajuda-mútua e autogestão, ver BARAVELLI, 2006. Sobre a história das cooperativas habitacionais uruguaias, desde a promulgação da Lei Nacional de Moradia, em dezembro de 1968, ver GHILARDI, 2017. 


\section{ENTRE A BASE E A DIREÇÃO, ONDE FICA O ARQUITETO?}

\section{I}

Entre meados de 1998 e 2000, a Usina trabalhou com o Movimento dos Trabalhadores Sem-Terra, o MST, numa das maiores ocupaçóes promovidas pela organização até aquele momento: o assentamento Ireno Alves dos Santos, na Fazenda Giacometi, na regiáo Centro-Oeste do Paraná. Situada às margens do Rio Iguaçu, justamente no ponto onde fora construída uma das grandes barragens nesse generoso corpo d'água (a barragem de Salto Santiago), a Fazenda incorporou, não se sabe por que obscuras razóes ou expedientes latifundiários, a vila barrageira que, entre o final dos anos 1970 e início dos 1980, abrigara em torno de 13 mil trabalhadores e suas famílias, entre operários, engenheiros, técnicos diversos e dirigentes.

O MST ocupou a Giacometi na madrugada do dia 17 de abril de 1996, depois de quase um mês de preparativos, organizando e conduzindo um inumerável grupo de trabalhadores sem-terra ${ }^{8}$ para a transposição da porteira e da frágil cerca que ladeava um de seus flancos - uma imagem brilhantemente notabilizada pela lente de Sebastiáo Salgado, creio que muitos a conhecem ${ }^{9}$. A partir dessa ocupaçáo, a Fazenda - que então contava com aproximadamente insustentáveis 93 mil hectares - acabou parcialmente desapropriada, cedendo perto de 27 mil hectares para o assentamento de 1.478 famílias de trabalhadores rurais.

Comumente, essas ocupaçóes agregam, num primeiro momento, todas as famílias ocupantes em alguma área central, dotada de alguma infraestrutura, enquanto são promovidas as negociaçóes com vistas à desapropriação. No caso, a sede da Fazenda cumpriu esse papel, acomodando o acampamento de 3.048 famílias. Posteriormente, quando o Instituto Nacional de Colonização e Reforma Agrária (INCRA) promoveu o parcelamento, a delimitação e a distribuição dos lotes, mais de 1.500 famílias acabaram constituindo um excedente que, aos poucos, foi se desmobilizando ou sendo absorvido por outras ocupaçóes e projetos de assentamentos.

Com a distribuição dos lotes e a constituição do módulo rural familiar sempre acaba ocorrendo uma ampla dispersáo populacional no território que, de certa forma, enfraquece bastante os mecanismos de conexão, diálogo e informação com o centro decisório, comprometendo, até certo ponto, a organicidade e densidade política de todo o grupo. Isso é uma situaçáo típica e recorrente e sempre foi motivo de várias discussões e debates em diversas instâncias do movimento.

Foi justamente nesse momento que a Usina entrou na história: percebendo as dificuldades impostas pela dispersão das quase 1.500 famílias, o MST passou a cogitar a possibilidade de fazer nascer, das ruínas daquele núcleo urbano construído para abrigar os trabalhadores na construção da barragem, uma nova "centralidade" para o assentamento - agora disposta como alternativa urbana propriamente dita à dispersão das unidades rurais. A ideia não era despropositada. Despropositado sim era o abandono da impressionante infraestrutura construída naquele lugar, sistematicamente planejado pela Eletrosul - Centrais Elétricas do Sul do Brasil S/A, responsável pela construção da barragem: reservatórios com 1,4 milhão de litros de capacidade para tratamento e distribuição de água potável, redes de drenagem quase intactas, ruas asfaltadas, dotadas de guias e sarjetas, piscinas nos clubes dos engenheiros e dos trabalhadores fixos, restos 
de um hospital para 68 leitos, tudo envolto pela mata que ali se formara ao longo de pelo menos uns 15 anos. No contexto do desenvolvimento dos trabalhos, chegamos a conversar com uma das arquitetas envolvidas no planejamento da vila barrageira de Salto Santiago. Nesta oportunidade, ela nos esclareceu que a política de mobilização da força de trabalho para a construçáo de barragens, na época, havia sofrido uma série de rearranjos, reorientando a prática instituída até então. A ideia de aglutinar boa parte da força de trabalho necessária numa espécie de "grande acampamento urbano provisório" procurava solucionar o problema da aglomeração populacional nas cidades vizinhas, ao longo da realização dos empreendimentos. Sem estrutura para acomodar milhares de trabalhadores e suas famílias, estes municípios amargavam, com a conclusão das obras, problemas decorrentes do inchaço de oferta de mão de obra e pouca demanda de trabalho. Daí, em lógica simples e pragmática, bastaria desmobilizar o tal "acampamento provisório" e mandar as pessoas buscarem cada um o rumo para sua vida. Foi assim que, em 1983, a vila barrageira de Salto Santiago foi desmobilizada, desmontada e, pelo que nos noticiaram os próprios assentados, vítima de frequentes assaltos e saques nas edificaçóes mais perenes (hospital, clubes, rodoviária etc. ${ }^{10}$. Mesmo assim, restara ali uma infraestrutura urbana impressionante, tanto em termos de extensão como em termos de qualidade, passível de recuperação e de uma nova mobilização urbanística - esta era a ideia do MST e por isso chamaram os arquitetos.

Passamos, então, a discutir intensamente o planejamento desse novo núcleo urbano - o qual os sem-terra insistiam em chamar de "a cidade da reforma agrária". A ideia era linda: já em agosto 1998, quando apresentamos algumas questôes para apreendermos o que os assentados e suas lideranças entendiam por "cidade", a resposta náo poderia ser mais motivadora - para quem se seduz com a possibilidade pouco frequente de revisitar, praticamente, as organizaçóes produtivas imaginadas por Owen ou Fourier, ou ainda as especulaçôes urbanísticas de Patrick Geddes. Lembro-me de um dos assentados - um dos mais articulados do grupo - dissertando sobre as possibilidades de uma "comunidade de produtores rurais", articulados em torno de um "comércio do que nós mesmos iremos produzir", de uma "escola que ensine cidadania para os nossos piás", de uma "universidade voltada para os problemas do campo" etc. - protagonistas autônomos de uma nova ideia de urbanidade, justamente gestada a partir de seu avesso. Na época, cunhamos a ideia de uma "cidadania sem cidade" (RIZEK; LOPES, 1999, p. 2), como argumento semântico que nos auxiliava a dar conta desse paradoxo, enunciando as possibilidades de realização, no campo, dos elementos constitutivos dos direitos e relaçóes democráticas aparentemente perpetrados e privilegiados pela dinâmica da concentração citadina.

Embalados pela ideia de construção dessa "nova urbanidade", estruturamos um processo de "Consulta Urbana”, com o auxílio do Programa de Gestión Urbana - o PGU (gerido pelo Centro das Naçóes Unidas para os Assentamentos Humanos - a agência HABITAT, ligada à Organização das Nações Unidas - ONU). Denominado "A cidade que queremos", o seminário transcorreu ao longo de duas gélidas semanas de julho de 2000, intercaladas por um período no qual nos dedicamos a trabalhar os resultados obtidos na primeira semana, para apresentação e debate na segunda semana. A ideia era que os resultados desse seminário fornecessem os insumos necessários para a elaboração de uma espécie de "plano diretor urbano-rural", que envolvesse não só a vila, como todo o assentamento.

Paralelamente, desenvolvíamos os projetos e acompanhávamos a construção
$10 \mathrm{Na}$ época do seminário que comento a seguir, tivemos acesso a slides e projetos da vila barrageira: era impressionante a qualidade das edificações ali construídas, dos equipamentos, infraestruturas e do desenho urbano ali realizado - o que só aumentava o caráter inusitado de toda aquela situação. 
$11 \mathrm{Um}$ relato mais extenso e cuidadoso desse caso foi publicado integralmente em Lopes, 2002. das primeiras 500 casas dos assentados na vila, financiadas pelos recursos que chegavam para a instalação das famílias - uma das rubricas dos recursos prescritos no Projeto de Assentamento. Uma cooperativa de mão-de-obra criada pelo MST local e por nós assessorada auxiliava na condução das obras (imagine o leitor o que era gerir um canteiro de obras de 1.500 famílias esparramadas em 27 mil hectares, mais uma vila em ruínas).

Não vou me estender nessa descrição, já o fiz em outro lugar ${ }^{11}$. Procurei construir aqui o relato apenas para destacar justamente esse quadro, caracterizado pelo paradoxo que é colocar lado a lado um processo de "Consulta Urbana" e a realidade da vida de um produtor rural. Pois não bastou começarmos a construir as primeiras casas para surgirem os questionamentos, advindos de todos os lados: se o recurso é para a "instalação" das famílias - e cada família só acessa uma única vez essa parcela desse recurso - para onde direcioná-lo? Para a "casa da cidade" ou para a "casa na propriedade"? E se o trabalhador rural tem que morar perto do lugar de sua produção, quem vai morar na "casa da cidade"? Não é necessário dizer que não poucos assentados viram aí uma excelente oportunidade imobiliária, acumulando lote urbano e rural como fonte de especulação. Além disso, o próprio parcelamento e a distribuição de "lotes" na vila, promovidos pelo INCRA, já desnorteava qualquer possibilidade de superação do desenho tradicional da cidade instituída. Alguns técnicos do Instituto, instados pelo poder político local e mesmo tendo participado da elaboraçáo do parcelamento da vila, passaram a ameaçar as famílias, condicionando a liberaçấo dos recursos para insumos e produção à opção pela instalação da casa na unidade rural - e não na "cidade".

Em meio a esse fogo cruzado, dávamos andamento à proposta de recuperação do núcleo da vila, tentando criar um ponto de referência minimamente "urbana" para todo o assentamento. A ideia era constituir ali um espaço para as festas do assentamento (chegamos a participar de uma), para centralizar o abastecimento e a distribuição de provisōes, para oferecer alguns atendimentos especializados, para os eventos promovidos pelo movimento e para funcionar como um núcleo de aglutinação política regional, controlado pelo MST - isso em meio a algumas das maiores cooperativas de produtores agroindustriais do país.

É claro que a mão forte das forças políticas hegemônicas não demorou a agir, esmagando, quase que literalmente, todas essas iniciativas, por vias diretas e, principalmente, indiretas. Uma das mais importantes lideranças locais do MST foi oportunamente acusada de estar envolvida na venda da produção de uma outra fazenda ocupada e foi presa, amargando um longo ano nas cadeias da região. Outras lideranças tiveram pior sorte, vítimas de misteriosos acidentes nas rodovias locais.

A COAGRI, entâo uma das maiores cooperativas do país vinculadas ao MST e com sede em Laranjeiras do Sul, viu-se envolvida num imbróglio com títulos podres da dívida pública, negociados na tentativa de salvar a produção de 2000/2001 (o Governo Federal atrasara a liberação dos recursos para a safra daquele período). Acuada pela imprensa e pelo próprio governo, à COAGRI só restava contar com a produção assegurada pelos próprios cooperados, obtida com seus próprios recursos. No entanto, à vista do "escândalo" envolvendo a Cooperativa, os cooperados acabaram vendendo sua produção a atravessadores, deixando a COAGRI exaurir-se em uma profunda crise de inanição que a levou à falência.

Eu mesmo tive problemas com o CREA do Paraná, que me acusou de "exercício ilegal da profissão" por falta de registro naquele estado. Sumiram com minha carteira 
que, naquele tempo, usava-se para anotaçóes como o registro profissional provisório fora da jurisdição à qual o profissional estava vinculado - que, por pura disciplina burocrática, havíamos providenciado quando demos início à aprovação dos projetos das casas que seriam construídas na vila. Em meio a essa confusão, um evento prosaico nos fez meditar bastante sobre nossa inserção como arquitetos e urbanistas num contexto táo conflitivo e sem protocolos conhecidos como este que acabo de relatar.

Numa de minhas visitas à vila, ao chegar de viagem, topei com uma faixa, estendida entre árvores logo na entrada da via que dava acesso à área que estávamos tentando fazer funcionar como o núcleo operacional da nova "cidade" e como sede da cooperativa de mão de obra que assessorávamos. Nela estava escrito, em letras capitais: "BREVE AQUI: MECÂNICA DE MOTOSERRAS E MOTORES". Comentei e reclamei sobre o assunto com um dos dirigentes do MST local, um gaúcho do oeste do Rio Grande do Sul, dizendo que aquela iniciativa atropelava toda a discussão que estávamos promovendo; que não sabia como agir numa situação como aquela, que a direção do movimento deveria tomar uma atitude enérgica para coibir iniciativas semelhantes, que náo era meu papel como assessor técnico intervir naquele contexto etc. A resposta foi bastante sintética e lacônica, em autêntico sotaque gaúcho: "Esse problema de identidade, de não saber se é base ou direção, é um problema de vocês, lá da cidade...”. Depois dessa conversa, fui até o lugar onde estava estendida a faixa e arranquei-a de lá, deixando o pessoal do escritório da cooperativa de mão de obra avisado que me procurassem, caso aparecesse alguém reclamando a retirada da faixa. Para minha sorte, ninguém apareceu.

\section{II}

Há um papel clássico, atribuído ao arquiteto, de agente responsável pela transmissão e reprodução da vontade e das ordens do contratante dos serviços. Sérgio Ferro, em A história da arquitetura vista do canteiro (2010), faz a gênese desse protagonismo profissional acompanhar a própria história do ressurgimento das cidades, entre os séculos XI e XII. Seguindo por esta senda, Ferro argumenta quanto ao papel das catedrais, muralhas e castelos, como "motor da acumulação primitiva do capital". A riqueza trazida para as cidades circulava pagando materiais e operários, os quais "comiam, se vestiam, consumiam a produção local, formando assim um mercado urbano" (FERRO, 2010, p. 15). Tal processo, viabilizando economicamente as cidades, acabava solapando o ímpeto que fazia o clero e a nobreza investirem naquelas estruturas: os negócios urbanos e o comércio exterior passam a ser mais atraentes como atividade econômica, relegando as grandes obras ao segundo plano, condenando-as ao inacabamento que lhes é característico.

Desse modo, as relaçóes de trabalho começam a mudar, principalmente lá pelo final do séc. XII: com o predomínio dos negócios, as corporações passam a se sujeitar a um ordenamento jurídico e a estruturas comerciais e de investimento que lhes são exógenas. Sérgio Ferro cita o caso de Estrasburgo como exemplar: "tornou-se uma espécie de República e as negociações ficaram mais complexas. Um conselho dirigia as obras [da catedral de Estrasburgo] e, para se obter um consenso, começou a ser necessário desenhar antes, fazer maquetes, prever. Surge assim a figura do intermediário, o que desenha o projeto-contrato". Sérgio denomina esse sujeito como um "protoarquiteto" e cita a figura de Mestre Erwin de Steinbach, transformado por Goethe e pelo mo- 
vimento neogótico no "grande herói da arquitetura gótica" (FERRO, 2010, p. 16).

De aí em diante, essa separação entre quem desenha e aqueles que constroem só irá se aprofundar.

André Gorz, em seu "Técnicos, técnica e luta de classes" também discute o papel dos técnicos, os quais contribuiriam organicamente para a "perpetuação da divisão hierárquica do trabalho" (GORZ, 1996, p. 235). Descreve a funcionalidade sistêmica dos "engenheiros, técnicos superiores e outros dirigentes investidos de funçôes de comando e de controle", a eles atribuindo ainda o papel de agentes de "desqualificação dos operários manuais e na separação arbitrária entre trabalho manual, reduzido a ser pura execução, e trabalho técnico de supervisão e de direção" (GORZ, 1996, p. 236).

Registro aqui a digressão histórica de Sérgio Ferro e a menção ao conhecido texto de Gorz para colocar em relevo o que me parece evidente no relato sobre a faixa do mecânico de motosserras em particular e na história do assentamento Ireno Alves e sua "cidade da reforma agrária" como um todo: a inexistência de um protocolo pré-definido, de uma "regra de conduta" estabelecida para um arquiteto naquela situação inusitada, coloca-nos novamente diante de uma realidade pouco afeita à conformaçóes práticas do ofício - menos afeita ainda a algum enquadramento semântico. O contato com essa realidade, sem as mediaçōes convencionais pré-estabelecidas para o exercício profissional, solapa as convicçóes mais entranhadas quanto ao que deva ser, objetivamente, um "arquiteto" e sua "arquitetura". O desenho, nesse caso, pouco importa: ele tem lugar apenas como "discurso competente", mas nem assim merece maior atenção. Desse modo, aquele papel discricionário, de intermediário onisciente, atribuído ao arquiteto e ao técnico em geral me parecem impertinentes e a dissonância anuncia que alguma coisa náo se ajusta ao figurino, que as variáveis aparecem fora do lugar, que as denominaçóes e seus significados não dão conta das explicaçóes necessárias. $\mathrm{E}$ não creio que se trate de uma peculiaridade engendrada por aquela situação: talvez o problema semântico e de identidade seja "um problema de vocês, lá da cidade".

\section{III}

Por outro lado, é justamente essa abordagem histórica de Ferro e a crítica de Gorz ao papel do técnico na hierarquia da produção capitalista - como intermediário na relação entre capital e trabalho - que nos demonstram quais são os conteúdos significantes do que é o ofício em sua representação mais acabada. Se as situaçôes que enquadrei dissonam dessa representação, então podemos cogitar que ou aqueles contextos não são próprios para a atuação dos arquitetos, não são de sua atribuição, ou o que entendemos como o papel dos arquitetos precisa passar por algumas reconsideraçôes. Por isso sugeri anteriormente que a questão talvez se tratasse de refundarmos o ofício.

Em geral, a pergunta sobre quais são os limites do campo profissional, em última instância, é sempre formulada a partir de uma noção pretensamente universal do que possa ser arquitetura. Parece-me que, nas situaçôes que aqui relatei, não só não se configura um protocolo semântico confiável pelo qual se faz possível o diálogo entre interlocutores, como sequer parece pertinente uma noção totalizante de arquitetura e de qual seja precisamente o papel do próprio arquiteto. Assim como a profissão em si não é campo homogêneo, o arquiteto que nele atua é "legiāo" - como diria o capeta sobre si mesmo.

Em certa altura de seu artigo, João Whitaker pergunta-se: "E a arquitetura, como 
se coloca frente a isso?”, isto é, frente aos processos que produzem segregação urbana, degeneração ambiental e aprofundamento das disparidades sociais e econômicas no contexto da produção do espaço (WHITAKER, 2011, p. 6). Não parece despropositado perguntar: qual "arquitetura" é essa que precisa tomar posição? Pela sequência do texto, o autor nos propóe uma possível apreensão indutiva: "Nesse processo que se intensifica, e apesar do esforço louvável de cada vez mais gente, a arquitetura tradicionalmente bastante menosprezada pelo mercado tem visíveis dificuldades em impor um novo padrão qualitativo de reflexão sobre o urbano" (idem, grifo nosso). Apesar de ser possível inferirmos a partir daí que se trata de uma versáo ilustrada de arquitetura, ainda permanece a questão: mesmo essa arquitetura, instruída e construída em boa parte pela lente acadêmica, também já sofre de presbiopia, não dando conta de perceber os contornos mais precisos de uma realidade que lhe aparece desfocada: o que seria, mais precisamente, esse "mercado"?

Ora, esse mesmo "mercado" - podemos afirmar isso com certa segurança - congrega, além de arquitetos, "clientes" e fornecedores, também "arquiteturas" absolutamente diversificadas - além de construção, muita construção, como diria Lúcio Costa.

Se apertarmos os olhos, perceberemos que essa diversidade de arquitetos e "arquiteturas" nos aparecerão até que bastante sintonizados com o "mercado", o que reproduz "pelo país o desastre urbano e ambiental que são nossas cidades" (WHITAKER, 2011, p. 6). Se tomarmos como exemplo a representação do CAU paulista para ensaiar o delineamento do perfil profissional predominante - o qual conforma, até certo ponto, o grosso do campo profissional atualmente em movimento, pelo menos no âmbito regional ${ }^{12}$-, verificaremos que a maior parte dos 56 conselheiros, bem como seus suplentes, se observado o curto apanhado curricular que segue o nome e a foto de cada um deles no sítio eletrônico da autarquia, é justamente composta por profissionais organicamente inseridos nesse tal "mercado" (tanto o mercado dos escritórios e empresas privadas como aquele do ensino de arquitetura e urbanismo, das escolas privadas) - teoricamente, o "mercado" que menospreza o arquiteto e sua arquitetura.

Vasos comunicantes, se (1) a maioria do campo profissional é formada por arquitetos "de mercado" e (2) boa parte desses profissionais, pelo regime de trabalho proposto nas instituiçóes privadas de ensino superior, é composta por aqueles que atuam também como docentes nos cursos de Arquitetura e Urbanismo oferecidos por estas instituiçôes, perguntamo-nos então se a maioria dos estudantes não seria formada não só para mas principalmente pelo mercado.

A elitização do ofício é indiscutível. Seu descolamento em relação aos problemas que afligem nossas cidades e a maior parcela de sua populaçấo é incontestável. Mas, para além dessa constatação, precisamos pensar no que fazer. Náo podemos nos deixar levar por uma visão reducionista da realidade, correndo o risco de ficarmos pregando sozinhos no deserto. O cotidiano e a prática profissional enfrentam uma realidade muitíssimo mais complexa, com muito mais nuances e ambiguidades, recusando interpretaçóes totalizantes, composiçóes dualistas ou enquadramentos semânticos muito apertados. A produção do espaço será sempre o lugar do contraditório, das antinomias, e nele o arquiteto - seja o de "mercado", seja o "ilustrado", seja "assessor" ou "assistente técnico" - terá sempre que enfrentar o que é, o que não é e o distinto do que é e do que não é - tudo ao mesmo tempo.
12 Ao longo dos últimos 3 anos fui conselheiro suplente do CAU/SP. Por uma série de razões, acabei frequentando com maior regularidade as sessões plenárias no último ano de mandato, em 2017. Sem resvalar nenhum julgamento pessoal, se tomasse como referência o perfil do grupo de conselheiros ali reunidos, restariam poucos que corresponderiam ao que imagino ser um "arquiteto" - o que pode ser uma armadilha da minha imaginação. 


\section{ARQUITETOS EM PROCESSO}

A título de conclusão, proponho duas considerações.

\section{I}

Rodrigo Lefèvre, em sua dissertação de mestrado, já lá no começo dos anos 1980, lembrava, a partir de Marx, que "toda a sociedade assume, em seu cotidiano, compromissos com a estrutura geral e com seus desdobramentos culturais". Isso para demonstrar que, a partir das atividades interferentes nessa estrutura geral, acabam aparecendo "as relaçóes entre o fazer e o pensar", as quais vertebrariam as preocupaçóes com o ensino e a formação em geral. No entanto, Rodrigo defende que o ensino no Brasil de sua época adotara "proposiçôes onde as relaçôes entre o pensar e o fazer ficam quase no nível de uma relação causa-efeito”. Assim, a teoria e o conceito precederiam a prática e o objeto, insinuando-se desse modo uma certa primazia do pensar em relação ao fazer. Após discutir os limites impostos ao pensamento frente à "quantidade enorme de conhecimentos sistematizados e organizados (...), impossível de ser absorvida por um indivíduo isolado", o autor conjetura o quão paradoxal se apresenta a tarefa de pensar e repensar o mundo a partir de um universo de conhecimentos individualmente inapreensível. É aí então que formula sua hipótese para superação do impasse:

Talvez a única possibilidade de transpor o paradoxo é supor que não é necessário o conhecimento de todo o universo científico para que o indivíduo possa se equilibrar em suas relaçóes com o mundo: mas essa suposição contém outras ideias que não a ideia de 'equilíbrio entre indivíduos e mundo' - são as ideias de relaçóes entre indivíduo e um 'pedaço do mundo', de relaçóes de grupos de indivíduos com o mundo e, fundamentalmente, de relaçóes entre indivíduos.

E conclui mais adiante:

Nesse sentido, pode ficar claro que o que tem se tornado fundamental para a formação não são mais aqueles 'pacotes' de conhecimentos básicos, mas a prática e a compreensão teórica parcial das relaçóes entre indivíduos, das relaçôes entre cada indivíduo e o grupo de indivíduos, das relaçóes entre cada indivíduo e o 'pedaço de mundo' que pode tocar com sua atividade (LEFÈVRE, 1981, p. 214 a 218).

A proximidade com a realidade dos sem-teto e dos sem-terra não é nenhuma vantagem em si mesma, mas concede aos arquitetos a possiblidade de apreender um universo de relaçóes que não está dado de bandeja nas formas tradicionais do aprendizado e do exercício da profissão. Vou defender aqui - à vista dos casos que apresentei e com a ajuda de Lefèvre - que a reinvenção do ofício passa necessariamente pelo embate direto com os problemas superestruturais da sociedade e, particularmente, pela invenção de uma relação qualitativamente transformada com o mundo, com a natureza e com os indivíduos que fazem uso dos objetos que colocamos no mundo - os "futuros utilizadores", como diria Yona Friedman, ou "grupos socioespaciais", como defende Silke Kapp. Iniciativas como os programas de residência profissional, as diversas modalidades de extensão universitária, a abertura das pesquisas acadêmicas 
à imersão nas dimensôes mais práticas de seus objetos, as atividades dos estudantes em escritórios-modelo e mesmo uma aproximação mais intensa entre estudantes e grupos de assessoria técnica, talvez nos auxiliem no esboço de uma nova ordem para o exercício profissional, destituindo o modelo pretensamente universal prefigurado pelo arquiteto personagem das revistas especializadas.

\section{II}

Lefevvre recusava uma relação não dialética entre o fazer e o pensar no processo de formação. Imaginava também, na sua proposta de "projeto de um acampamento de obra" - onde o fazer e o aprender se sucediam recorrentemente no mesmo espaço e no mesmo tempo - que as mudanças ocorreriam numa "época de transição". Esse período, contudo, náo deixaria de propor possibilidades, "formas novas de organização das pessoas, formas novas de relaçôes de produçáa”. De todo modo, "essa época de transição, como observa Roberto Segre, onde haverá uma grande complexidade de desenvolvimento político e econômico, implicará na persistência de profundas contradiçôes". Referindo-se ao período imediatamente seguinte à Revolução Cubana e à participação dos arquitetos na construção de um novo jeito de pensar o país, Lefèvre registra o depoimento de Segre quanto à diversidade dos caminhos a serem experimentados: essa diversidade permitiria,

em um período no qual ainda não se fala de planificação, a coexistência de critérios contrastantes, os desníveis de qualidade, a variaçáo de soluçóes para um mesmo tema, a antinomia entre um vocabulário esquemático e primário e outro complexo e elaborado intelectualmente... (SEGRE apud LEFÈVRE, 1981, p. 45 a 47).

Certamente não passamos por uma revolução socialista, muito pelo contrário: vítimas de um golpe de caráter institucional, seguimos amargando a desmontagem do pouco que se construiu, a duras penas, em termos de políticas sociais e instituiçóes democráticas desde o final dos anos 1980. Mas certamente também precisamos recusar uma relação não dialética com o tempo e a realidade política e social em que vivemos: perseguindo uma abordagem dialética em relação ao tempo presente, não seria impensável que também vivemos, de outros modos, "épocas de transição" e, portanto, também sujeitos às antinomias "entre um vocabulário esquemático e primário e outro complexo e elaborado intelectualmente" (Deleuze, 1992. p. 217). As precisóes semânticas são fundamentais, como já afirmei, principalmente para um ajuste crítico mais cuidadoso dos nossos empreendimentos práticos. Mas elas não podem aprisionar a prática, a ponto de inibir a invenção de outras possibilidades de atuarmos no mundo. Segundo Deleuze, a palavra e a comunicação já estáo contaminadas, talvez completamente "apodrecidas": "O importante talvez venha a ser criar vacúolos de não-comunicação, interruptores, para escapar ao controle" (ibidem, p. 217). Por mais que nos espantemos quando damos conta do grau de heteronomia das açóes propostas pelos "projetos" que ajudamos a construir, não seria justo recusarmos profeticamente seu futuro, apenas porque náo reconhecemos naqueles os sentidos e representaçóes particulares que ali investimos. Quem conhece a ordem dos fatos? A ação pode prescrever a teoria e vice-versa. Até imagino possível agir sem pensar. Mas produzir teoria sem acreditar na ação parece-me um expediente bastante inócuo. 
João Marcos de Almeida Lopes é Arquiteto e Urbanista; professor Associado do Instituto de Arquitetura e Urbanismo da Universidade de São Paulo e do Programa de Pós-graduação do IAU-USP; fundador e atualmente associado da USINA - Centro de Trabalhos para o Ambiente Habitado.

E-mail:jmalopes@sc.usp.br

Artigo recebido em 09 de fevereiro de 2018 e aprovado para publicação em 07 de março de 2018.
Acreditar no mundo é o que mais nos falta; nós perdemos completamente o mundo, nos desapossaram dele. Acreditar no mundo significa principalmente suscitar acontecimentos, mesmo pequenos, que escapem ao controle, ou engendrar novos espaços-tempos, mesmo de superfície ou volume reduzidos. (...) É ao nível de cada tentativa que se avalia a capacidade de resistência ou, ao contrário, a submissão a um controle. Necessita-se ao mesmo tempo de criação e povo (DELEUZE, 1992, p. 218).

\section{REFERÊNCIAS BIBLIOGRÁFICAS}

BARAVELLI, José Eduardo. O cooperativismo uruguaio na habitação social de São Paulo: das cooperativas FUCVAM à Associação de Moradia Unidos de Vila Nova Cachoeirinha. 2006. Dissertação (Mestrado) - Faculdade de Arquitetura e Urbanismo, USP, São Paulo, 2006.

CHAUÍ, Marilena; FRANCO, Maria Sylvia Carvalho. Ideologia e mobilização popular. Rio de Janeiro: Paz e Terra / Centro de Estudos de Cultura Contemporânea, 1978.

CONSELHO DE ARQUITETURA E URBANISMO NO BRASIL (CAU). 56 PLENÁRIA: CAU destinará recursos para assistência técnica de habitação social. CAU/ BR: Conselho de Arquitetura e Urbanismo do Brasil, $1^{\circ}$ ago. 2016. Disponível em $<$ http://www.caubr.gov.br/56a-plenaria-cau-destinara-recursos-para-projetos-e-obrasde-assistencia-tecnica/>. Acesso em: jan. 2018.

DAGNINO, Evelina. Sociedade civil e espaços públicos no Brasil. São Paulo: Paz e Terra, 2002.

DELEUZE, Gilles. Conversaçôes: 1972-1990. Rio de Janeiro: Editora 34, 1992.

DEMARTINI, Juliana. Assessoria técnica continuada: desafios e possibilidades para a implementação de um programa público para as expressões do morar. 2016. Dissertação (Mestrado) - Universidade Federal do Rio de Janeiro, Rio de Janeiro, 2016.

FERRO, Sérgio. A história da arquitetura vista do canteiro: três aulas de Sérgio Ferro. São Paulo: GFAU, 2010.

GHILARDI, Flavio Henrique. Cinco década de cooperativismo de moradia no Uruguai. Revista e-metropolis, n. 30, ano 8, 2017. Disponível em: <http://emetropolis.net/artigo/225? name=cinco-decadas-de-cooperativismo-de-moradia-no-uruguai $>$. Acesso em: mar. 2018.

GORZ, André. Técnicos, técnica e luta de classes. Crítica da divisão do trabalho. São Paulo: Martins Fontes, 1996. p. 211-248

INSTITUTO DOS ARQUITETOS DO BRASIL (IAB). Manual para a implantação da assistência técnica pública e gratuita a famílias de baixa renda para projeto e construção de habitação de interesse social. Brasília: IAB/CEF/FNA, 2010.

LEFÈVRE, Rodrigo. Projeto de um acampamento de obra: uma utopia. Dissertação (Mestrado) - Faculdade de Arquitetura e Urbanismo, USP, São Paulo, 1981.

LOPES, J. M. A. O dorso da cidade: os sem-terra e a concepção de uma outra cidade. In: SANTOS, Boaventura de Sousa. Produzir para viver: os caminhos da produção não capitalista. Rio de Janeiro: Civilização Brasileira, 2002. p. 283-326. (Reinventar a emancipaçáo social: para novos manifestos, vol. 2).

LOPES, J. M. A.; RIZEK, Cibele Saliba. O mutirão autogerido como procedimento inovador na produção da moradia para os pobres: uma abordagem crítica. Procedimentos de gestão habitacional para população de baixa renda. v. 1. 1. ed. Porto Alegre: ANTAC, 2006. p. 52-83. (Coletânea Habitare, 5).

RIZEK, Cibele Saliba; LOPES, J. M. A. A cidade dos sem-terra: conflitos, imagens e práticas em torno da fundação da primeira cidade dos sem-terra do Brasil. Comunicação 
apresentada no Colóquio Cultures Civiques et Democracies Urbaines. Cerisy-laSalle, França, 12 a 17 de junho de 1999 (mimeo).

SANTO AMORE, Caio. Assessoria e assistência técnica: arquitetura e comunidade na política pública de habitação de interesse social. II UrbFavelas - Seminário nacional sobre urbanização de favelas, Rio de Janeiro, 2016. In: CARVALHO, Solange et al. Anais do II UrbFavelas. Rio de Janeiro: Letra Capital, 2017. Disponível em: <http:// www.sisgeenco.com.br/sistema/urbfavelas/anais2016/ARQUIVOS/GT4-207-21620160815014417.pdf>. Acesso em: jan. 2018.

SEMINÁRIO discute Assistência Técnica em Habitação de Interesse Social - ATHIS. CAU/ SP: Conselho de Arquitetura e Urbanismo de Sáo Paulo, 17 nov. 2017. Disponível em $<$ http://www.causp.gov.br/seminario-discute-assistencia-tecnica-em-habitacao-de-interesse-social-athis/>. Acesso em: jan. 2018.

VILAÇA, Ícaro; CONSTANTE, Paula (Orgs.). USINA: entre o projeto e o canteiro. São Paulo: Aurora, 2016.

WHITAKER, João Sette. Perspectivas e desafios para o jovem arquiteto no Brasil. Qual o papel da profissão? Arquitextos/Vitruvius, São Paulo, ano 12, n. 133.07, , jul. 2011. Disponível em: <http://www.vitruvius.com.br/revistas/read/arquitextos/12.133/3950>. Acesso em: jan. 2018. 